\title{
Wyniki leczenia wemurafenibem chorych na zaawansowanego czerniaka w ramach programu lekowego w Polsce
}

\author{
Joanna Stępniak ${ }^{1 *}$, Katarzyna Kozak ${ }^{1 *}$, Tomasz Świtaj ${ }^{1}$, Marek Ziobro², Ewa Kalinka-Warzocha ${ }^{3}$, \\ Marek Wojtukiewicz ${ }^{4}$, Elżbieta Nowara ${ }^{6}$, Hanna Koseła-Paterczyk ${ }^{1}$, Małgorzata Mroczek ${ }^{3}$, \\ Piotr Skalij ${ }^{4}$, Beata Jagielska ${ }^{5}$, Sławomir Falkowski ${ }^{1}$, Anna Klimczak ${ }^{1}$, Paweł Rogala ${ }^{1}$, \\ Milena Szacht ${ }^{1}$, Iwona Ługowska ${ }^{1}$, Piotr Rutkowski ${ }^{1}$
}

Wstęp. Czerniak należy do heterogennej grupy nowotworów o bardzo złym rokowaniu w przypadku rozsiewu choroby. U ponad połowy chorych na czerniaka skóry stwierdza się obecność mutacji w obrębie genu BRAF. Wemurafenib jest inhibitorem kinazy BRAF stosowanym w leczeniu chorych na zaawansowanego czerniaka z mutacją BRAF, który poprawia u nich czas przeżycia wolny od progresji choroby oraz przeżycia całkowitego. Celem pracy jest analiza wyników leczenia oraz bezpieczeństwa terapii wemurafenibem u chorych leczonych w ramach programu lekowego w Polsce. Materiały i metody. W okresie od października 2013 do kwietnia 2015 roku leczonych było 189 chorych (90 kobiet i 99 mężczyzn) z rozpoznaniem nieresekcyjnego/przerzutowego czerniaka z mutacją BRAFV600. Chorzy otrzymywali wemurafenib w dawce wyjściowej 960 mg dwa razy na dobę. Oceniano czas wolny od progresji choroby, czas przeżycia całkowitego oraz monitorowano działania niepożądane. Do analizy przeżycia użyto metody Kaplana-Meiera oraz testu logarytmicznego rang (log-rank) dla analiz dwuczynnikowych.

Wyniki. W pierwszej ocenie skuteczności leczenia u 8 chorych (4,3\%) stwierdzono całkowitą odpowiedź, u 75 chorych $(39,7 \%)$ częściową odpowiedź, u 62 chorych $(32,8 \%)$ stabilizację choroby, a u 44 chorych $(23,2 \%)$ progresję choroby. Kontrolę choroby wykazano u $76,7 \%$ chorych. Po progresji w trakcie terapii wemurafenibem $27 \%$ chorych otrzymało kolejne linie leczenia systemowego - 28 chorych chemioterapię, 22 chorych ipilimumab. Podczas ostatniej analizy z dnia 5 września 2015 mediana czasu obserwacji dla żyjących chorych wyniosła 8 miesięcy (zakres 3-26). Mediana przeżycia wolnego od progresji wyniosła 6,7 miesiąca. Mediana czasu całkowitego przeżycia wyniosła 12 miesięcy. U 146 chorych (77\%) stwierdzono działania niepożądane, głównie pod postacią toksyczności skórnej w stopniu 1.i 2., u 32 chorych (17\%) objawy uboczne w 3.-4. stopniu toksyczności. U dwóch chorych zakończono leczenie z powodu toksyczności. Nie było zgonów spowodowanych toksycznością leczenia.

${ }^{1}$ Klinika Nowotworów Tkanek Miękkich, Kości i Czerniaków

Centrum Onkologii — Instytut im. Marii Skłodowskiej-Curie w Warszawie

${ }^{2}$ Klinika Nowotworów Układowych i Uogólnionych

Centrum Onkologii — Instytut im. Marii Skłodowskiej-Curie, Oddział w Krakowie

${ }^{3}$ Oddział Chemioterapii

Wojewódzki Szpital Specjalistyczny im. Mikołaja Kopernika w Łodzi

${ }^{4}$ Oddział Onkologii Klinicznej im. dr Ewy Pileckiej z Pododdziałem Chemioterapii Dziennej Białostockie Centrum Onkologii im. Marii Skłodowskiej-Curie

${ }^{5}$ Klinika Onkologii i Chorób Wewnętrznych

Centrum Onkologii — Instytut im. Marii Skłodowskiej-Curie w Warszawie

${ }^{6}$ Klinika Onkologii Klinicznej i Doświadczalnej

Centrum Onkologii — Instytut im. Marii Skłodowskiej-Curie, Oddział w Gliwicach

*Obie autorki w jednakowym stopniu przyczyniły się do powstania pracy 
Wnioski. Przeprowadzona analiza wieloośrodkowa potwierdziła skuteczność i bezpieczeństwo leczenia wemurafenibem w rutynowej praktyce klinicznej w heterogennej grupie zaawansowanych czerniaków z obecnością mutacji BRAF. Potwierdzono wagę znanych czynników prognostycznych dla całkowitego przeżycia w tej grupie chorych, takich jak aktywność dehydrogenazy mleczanowej (LDH) i wyjściowy stan sprawności wg ECOG. Obecne przeżycia chorych w grupie przerzutowych czerniaków z mutacją BRAF są dłuższe niż obserwowane w próbach historycznych.

\section{Results for advanced melanoma therapy with vemurafenib in a Polish drug programme}

Introduction. Melanoma is a heterogeneous group of tumours with poor prognosis if the disease is metastatic. More than half of patients with melanoma of the skin have detectable mutations in the BRAF gene. Vemurafenib is the BRAF kinase inhibitor used in the treatment of patients with advanced melanoma with the BRAF mutation. This improves time to progression-free survival and overall survival in patients with this diagnosis. The aim of the study was to analyse the results of treatment and safety of vemurafenib in patients treated during the Polish drug programme. Materials and methods Between October 2013 and April 2015 a total of 189 patients were treated, 90 women and 99 men, who had previously been diagnosed with unresectable/metastatic melanoma with BRAF V600 mutation. Patients received vemurafenib in $960 \mathrm{mg}$ dose twice per day. The estimated progression-free survival, overall survival and adverse events were assessed. For the survival analysis the Kaplan-Meier method and log-rank test (log-rank) for multi-factor analysis were used.

Results. In the first evaluation of the effectiveness of treatment, 8 patients (4.3\%) had a complete response, 75 patients (39.7\%) partial response, 62 patients (32.8\%) had stable disease, and 44 patients (23.2\%) had progression of the disease. The disease was controlled in $76.7 \%$ of patients. After progression during the therapy with vemurafenib $27 \%$ of the patients received subsequent lines of systemic therapy. Twenty-eight patients received chemotherapy and 22 patients immunotherapy with ipilimumab. During the last analysis dated 5 September 2015 , the median observation time for still living patients was 8 months (range 3-26). Median progression-free survival was 6.7 months. The median overall survival was 12 months. 146 patients (77\%) had adverse events, mostly in the form of dermal toxicity of Grades 1 and 2. Thirty-two patients (17\%) presented with side effects of the 3rd and 4th grades of toxicity. Two patients had to stop the treatment due to the toxicity. There were no deaths reported due to the toxicity of treatment.

Conclusions. The multicentre analysis confirmed the efficacy and safety of vemurafenib in routine clinical practice in a heterogeneous group of advanced melanomas with BRAF mutation. We confirmed the importance of the known prognostic factors for overall survival in this group of patients, such as lactate dehydogenaze activity (LDH) and ECOG performance status. The current survival of patients with the metastatic melanomas with BRAF mutations are longer than those observed in historical groups.

NOWOTWORY J Oncol 2016; 66, 2: 118-126

Słowa kluczowe: czerniak, mutacja BRAF V600, wemurafenib, inhibitory BRAF

Key words: melanoma, BRAF V600 mutation, vemurafenib, BRAF inhibitors

\section{Wstęp}

Czerniak należy do heterogennej grupy nowotworów związanej z licznymi zaburzeniami molekularnymi [1]. W komórkach większości czerniaków obserwuje się nadaktywność szlaku RAS/RAF/MEK/ERK, przekazującego sygnały z receptorów dla czynników wzrostu, co odgrywa główną rolę $w$ regulacji proliferacji komórkowej, w inwazji nowotworu i przeżyciu jego komórek [2-6]. Najczęściej wynika to z obecności mutacji aktywujących poszczególne składowe tego szlaku, w ponad połowie czerniaków skóry - genu $\operatorname{BRAF}[3,4]$. Wemurafenib, będący inhibitorem kinazy BRAF, wydłuża przeżycia wolne od progresji choroby oraz przeżycia całkowite u chorych na zaawansowanego czerniaka z mutacją BRAFV600. Lek został zarejestrowany w 2011 r. na podstawie wyników randomizowanego badania III fazy porównującego skuteczność wemurafenibu z dakarbazyną w I linii leczenia chorych na nieresekcyjnego lub przerzutowego czerniaka z mutacją V600 [7, 8]. Wyniki nowo opublikowanego, wieloośrodkowego badania oceniającego bezpieczeństwo terapii i obejmującego grupę ponad 3000 chorych potwierdziło skuteczność i bezpieczeństwo leczenia wemurafenibem [9]. Celem niniejszej analizy jest ocena wyników leczenia oraz bezpieczeństwa terapii wemurafenibem u chorych leczonych wramach programulekowegow codziennejpraktyceklinicznej w 5 polskich ośrodkach onkologicznych.

\section{Metody i materiały}

W okresie od października 2013 r. do kwietnia 2015 r. leczonych było 189 chorych (90 kobiet i 99 mężczyzn) z rozpoznaniem nieresekcyjnego lub przerzutowego czer- 
Tabela I. Charakterystyka chorych leczonych wemurafenibem w ramach programu lekowego

\begin{tabular}{lcc}
\hline Czynnik kliniczno- & $\begin{array}{c}\text { Liczba chorych } \\
\text {-p }=189\end{array}$ & Odsetek \\
\hline Płé́: & & \\
$\quad$ mężczyźni & 99 & $52 \%$ \\
$\quad$ kobiety & 90 & $48 \%$ \\
Ilinia leczenia & 147 & $78 \%$ \\
II linia leczenia & 42 & $22 \%$ \\
Stopień sprawności: & & \\
$\quad$ PS 0 wg ECOG & 82 & $43 \%$ \\
PS 1 wg ECOG & 107 & $57 \%$ \\
Stopień zaawansowania wg: & & \\
$\quad$ AJCC & & \\
M1a & 8 & $6 \%$ \\
M1b & 11 & $7 \%$ \\
M1c & 131 & $87 \%$ \\
brak danych & 39 & \\
Wyjściowa aktywność LDH: & & \\
w normie & 126 & $67 \%$ \\
$\quad$ zwiększona & 63 & $33 \%$ \\
Przerzuty do OUN przy & & \\
rozpoczęciu terapii: & & \\
$\quad$ obecne \\
nie stwierdzono
\end{tabular}

niaka z potwierdzoną za pomocą zwalidowanego testu mutacją BRFAF w 5 ośrodkach onkologicznych, tj. w Białymstoku, Gliwicach, Krakowie, Łodzi i Warszawie. Chorzy otrzymywali wemurafenib w dawce początkowej $960 \mathrm{mg}$ 2 razy dziennie.

Do programu lekowego włączano chorych spełniających jego kryteria, z tym że od marca 2015 roku leczenie wemurafenibem zostało ograniczone jedynie do pierwszej linii terapii. Chorzy otrzymywali wyjściowo wemurafenib w dawce 2 razy $960 \mathrm{mg} /$ dobę.

Mediana wieku w momencie rozpoznania wynosiła 55 lat (zakres 24-91) (tab. I). Czterdziestu dwóch (22\%) chorych otrzymywało wcześniej leczenie systemowe, głównie chemioterapię opartą na dakarbazynie, 6 (3\%) chorych otrzymywało wcześniej immunoterapię w ramach badań klinicznych. Stan sprawności (PS - performance status) w stopniu 0 według kryteriów Eastern Cooperative Oncology Group (ECOG) stwierdzono u 82 chorych (43\%), 1 wg ECOG u 107 chorych (57\%). U 72 (38\%) chorych stwierdzono bezobjawowe przerzuty czerniaka do ośrodkowego układu nerwowego (OUN) przed rozpoczęciem leczenia wemurafenibem. Aktywność dehydrogenazy mleczanowej (LDH) w momencie rozpoczęcia leczenia była zwiększona u 63 chorych (33\%). Te trzy czynniki oceniano jako główne punkty mające potencjalnie wpływ na wyniki leczenia. Ostatnia obserwacja chorych miała miejsce 5 września 2015 roku — mediana czasu obserwacji dla żyjących chorych wyniosła 8 miesięcy (zakres: 3-26). W celu monitorowania odpowiedzi na leczenie przeprowadzano ocenę wielkości zmian nowotworowych przy zastosowaniu badań obrazowych, takich jak tomografia komputerowa czy rezonans magnetyczny (co 8-10 tygodni). Odpowiedź na leczenie oceniana była przy zastosowaniu skali RECIST 1.1 (Response Evaluation Criteria In Solid Tumours). Dane dotyczące tolerancji leczenia przedstawiono zgodnie z czwartą wersją skali oceny toksyczności leczenia CTCAE (Common Terminology Criteria for Adverse Events). Do analizy przeżycia użyto metody Kaplana-Meiera oraz testu logarytmicznego rang (log-rank) dla analiz dwuczynnikowych. Analiza statystyczna była wykonana przy użyciu programu Statistica.

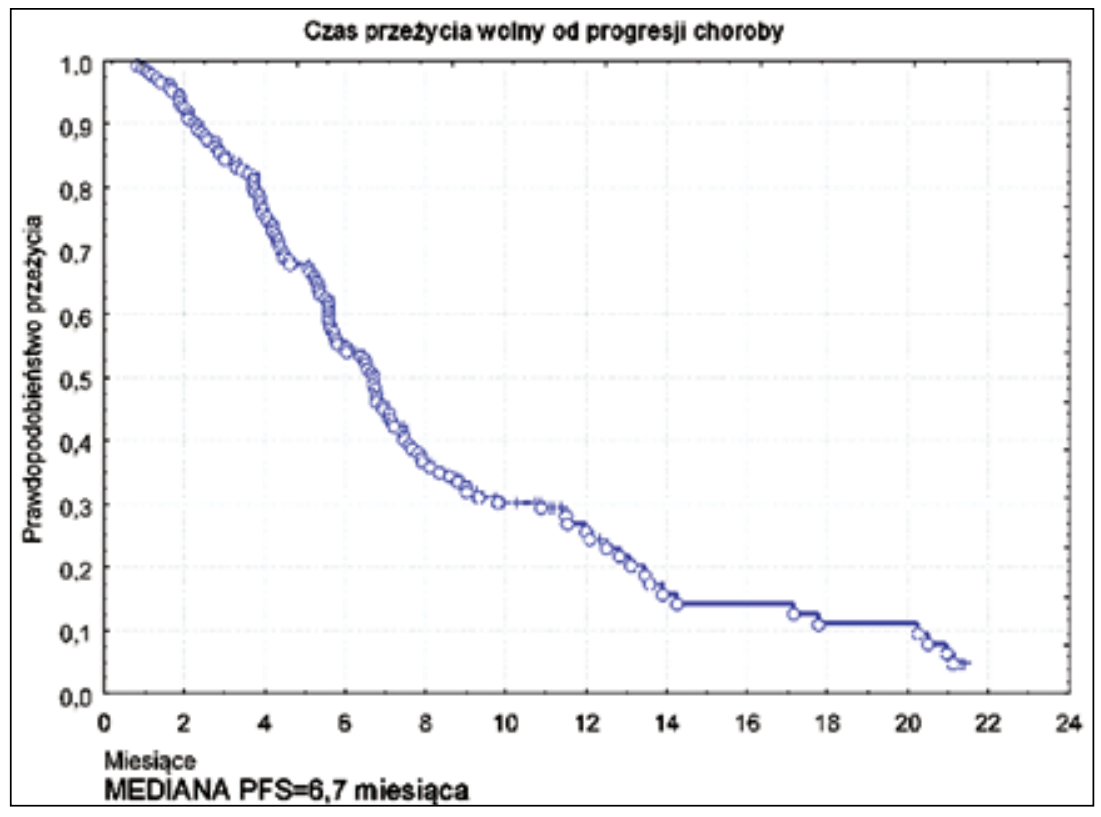

Rycina 1. Krzywa Kaplana-Meiera przedstawiająca przeżycia wolne od progresji choroby u chorych leczonych wemurafenibem 


\section{Wyniki}

Najlepsze odpowiedzi na leczenie obejmowały całkowitą odpowiedź u 8 (4,3\%) chorych, częściową odpowiedź u 75 (39,7\%) chorych, u 62 (32,8\%) chorych wykazano stabilizację, a u $44(23,2 \%)$ chorych stwierdzono progresję choroby. Ogółem u 76,7 \% chorych uzyskano kontrolę choroby. Po progresji w trakcie terapii wemurafenibem $27 \%$ chorych otrzymało kolejne linie leczenia systemowego - 28 chorych otrzymało w kolejnej linii chemioterapię, a 22 chorych ipilimumab. W momencie analizy nie żyło 104 chorych.

Mediana przeżycia wolnego od progresji (PFS - progression-free survival) wyniosła 6,7 miesiąca (ryc. 1) i istotnie korelowała z poziomem LDH, wyjściowym stanem sprawności ECOG, stopniem zaawansowania M1a, M1b vs M1c, obecnością przerzutów czerniaka w obrębie OUN oraz faktem wcześniejszego leczenia systemowego (tab. II). Mediana PFS w grupie chorych z aktywnością LDH w normie przy rozpoczęciu leczenia wyniosła 7,8 miesiąca vs 5,2 miesiąca w grupie chorych z podwyższoną aktywnością LDH (ryc. 2A). Mediana PFS w grupie chorych z PS 0 wg ECOG wyniosła 8 vs 5,5 miesiąca w grupie chorych ze stanem sprawności 1 wg ECOG (ryc. 2B). Mediana PFS w grupie chorych bez stwierdzonych przerzutów w obrębie OUN wyniosła 7,1 vs 5,6 miesiąca w grupie chorych ze stabilnymi zmianami w mózgu (ryc. 2C). Wykazano tym samym, że na poprawę przeżycia wolnego od progresji wpływa lepszy wyjściowo stan sprawności ( $p=0,001$; roczne PFS dla ECOG 0 vs 1, odpowiednio $37 \%$ vs $19 \%$ ), prawidłowa wyjściowo aktywność LDH (35\% vs 15\%, $\mathrm{p}=0,001)$, brak przerzutów do OUN (36\% vs $14 \%, \mathrm{p}=0,002)$. Ponadto udowodniono, że na poprawę PFS wpływa również niższy stopień zaawansowania M1a $(p=0,04)$. Mediana PFS choroby zależała także od tego, czy chory był wcześniej leczony; w tej grupie mediana PFS wśród chorych wcześniej nieleczonych wyniosła 6,9 vs 5,3 miesiąca $w$ grupie chorych otrzymujących wemurafenib w ramach leczenia drugiej linii $(p<0,05)$ (ryc. 3).

Mediana czasu całkowitego przeżycia (OS - overall survival) wyniosła 12 miesięcy (ryc. 4) i wykazano istotną korelację z wyjściową aktywnością LDH, stanem sprawności wg ECOG, stopniem zaawansowania M1a, M1b vs M1c (tab. II). Mediana OS w grupie chorych z poziomem LDH w normie przy rozpoczęciu leczenia wyniosła 12,8 miesiąca vs 9,6 w grupie chorych z podwyższoną aktywnością LDH (ryc. 5A). Mediana OS w grupie chorych w stopniu sprawności 0 wg ECOG wyniosła 12,5 vs 9,7 miesiąca w grupie chorych ze stanem sprawności 1 wg ECOG (ryc. 5B). Mediana OS w grupie chorych bez stwierdzonych przerzutów w obrębie OUN wyniosła 12,2 vs 9,8 miesiąca w grupie chorych z przerzutami do mózgu (ryc. 5C). Na dłuższe przeżycia całkowite wpływ miał więc lepszy wyjściowo stan sprawności (18-miesięczne OS dla ECOG 0 vs 1, 32\% vs 20\%, p < 0,02), prawidłowa aktywność LDH (30\% vs $20 \%, \mathrm{p}=0,04)$ oraz stopień zaawansowania M1a i M1b w porównaniu z M1c
( $42 \%$ vs $40 \%$ vs $21 \%, p=0,05$ ). Nie stwierdzono różnic w OS w zależności od faktu leczenia wemurafenibem w I lub II linii (ryc. 6).

U 146 chorych (77\%) stwierdzono jakiekolwiek działania niepożądane leczenia, u jedynie dwóch chorych przerwano leczenie z powodu toksyczności. Dominowała toksyczność skórna (tj. wysypka, wypadanie włosów, fototoksyczność, zespół ręka-stopa w stopniu 1.i 2.) często samoistnie ustępująca, niewymagająca dłuższego leczenia, a niekiedy jedynie czasowego odstawienia leczenia i modyfikacji dawki. Nie było zgonów spowodowanych zdarzeniami niepożądanymi związanymi z terapią, natomiast u 32 chorych (17\%) wystąpiły objawy uboczne w 3.-4. stopniu toksyczności. U 6 chorych stwierdzono hepatotoksyczność w stopniu CTCAE 3.

\section{Dyskusja}

Poznanie zaburzeń genetycznych występujących w czerniaku, w tym zaburzeń w zakresie szlaku RAS/RAF/MAPK prowadzących do nadaktywności w przekazywaniu sygnałów z receptorów dla czynników wzrostu, pozwoliło na rozwój leczenia ukierunkowanego molekularnie. Wemurafenib jest pierwszym lekiem należącym do grupy inhibitorów BRAF zarejestrowanym do leczenia zaawansowanego czerniaka, który wydłuża czas przeżyć całkowitych u chorych z tym rozpoznaniem [7]. W badaniach klinicznych I, II i III fazy przeprowadzonych w grupie chorych na zaawansowanego czerniaka z obecnością mutacji BRAF V600 wykazano wysoką skuteczność tego leku w postaci wysokiego odsetka odpowiedzi na leczenie (48\%-53\%) oraz wydłużenia przeżycia wolnego od progresji choroby. Korzyść z leczenia mają chorzy niezależnie od wieku, płci, stopnia sprawności, linii leczenia systemowego, obecności przerzutów do OUN, stopnia zaawansowania czy aktywności LDH [8, 9], część z tych czynników wpływa jednak na dłuższe PFS i OS podczas terapii wemurafenibem. Mediana PFS wynosząca około 7 miesięcy i OS około roku w naszej grupie chorych leczonych w ramach programu lekowego jest zbliżona do danych opublikowanych w badaniu bezpieczeństwa terapii na 3222 chorych, z czego połowa otrzymała już wcześniej leczenie systemowe z powodu zaawansowanego czerniaka $[9,10]$. Obecne wskaźniki przeżyć przy leczeniu wemurafenibem są około dwa razy wyższe niż wcześniej obserwowane w grupie zaawansowanych chorych z obecnością mutacji $B R A F$ [11]. Problemem w rutynowej praktyce klinicznej jest stosunkowo krótki czas trwania odpowiedzi na leczenie, co związane jest z nabytą po pewnym czasie opornością na lek podczas stosowania wemurafenibu w monoterapii. Dołączenie innego inhibitora szlaku kinaz MAP, takiego jak inhibitor MEK, opóźnia wystąpienie nabytej oporności i poprawia zahamowanie rozwoju nowotworu [12]. Badanie III fazy porównujące stosowanie wemurafenibu w monoterapii do kombinacji wemurafenibu $z$ inhibitorem MEK (kobimetynibem) wykazało, że grupa otrzymująca leczenie 
A Czas przežycia wolny od progresji choroby w zaleznosci od wyjściowego poziomu LDH

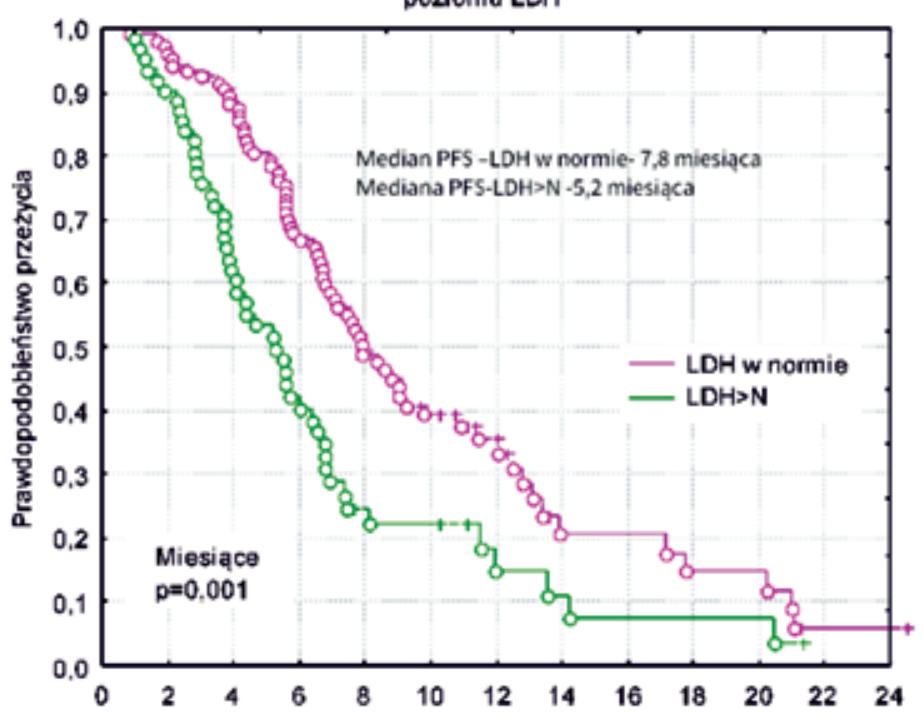

B Czas przezycia wolny od progresji choroby w zaleznosci od wyjsciowego ECOG

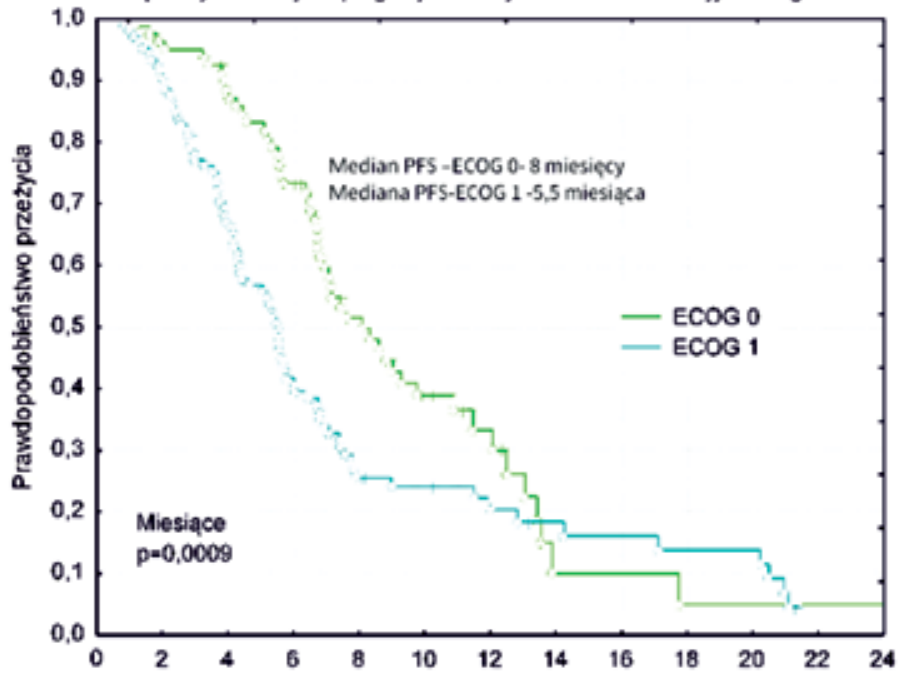

C Czas przezy cia wolny od progresji choroby w zaleznosci od obecnosci przerzutów do ouN

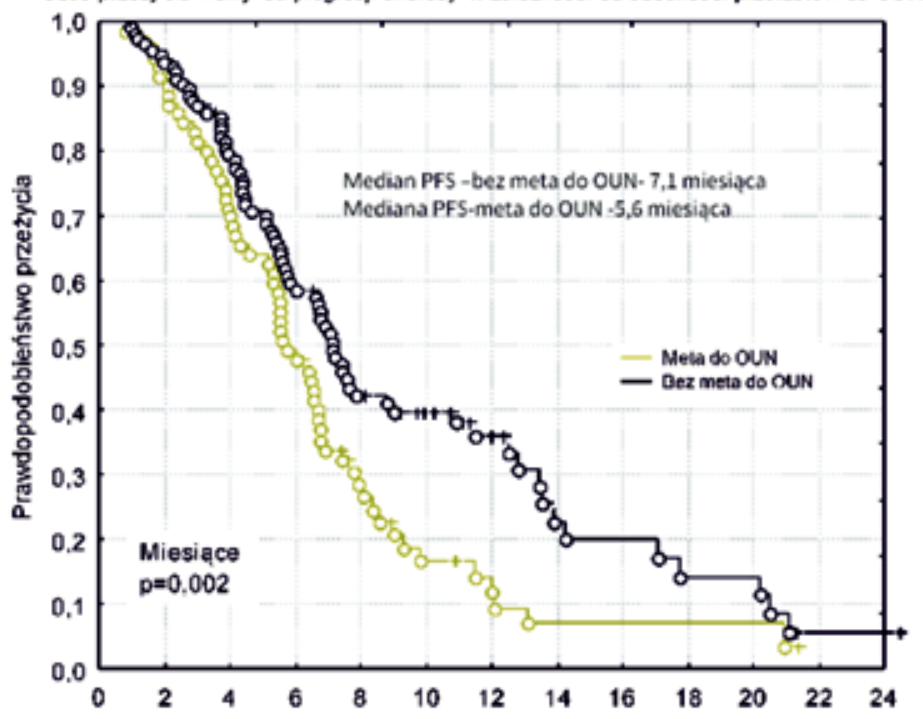

Rycina 2A, B, C. Przeżycia wolne od progresji choroby w zależności od wyjściowej aktywności dehydrogenazy mleczanowej (LDH) — A, stanu sprawności według skali ECOG (Eastern Cooperative Oncology Group) — B oraz obecności zmian przerzutowych w obrębie ośrodkowego układu nerwowego $-\mathrm{C}$ 


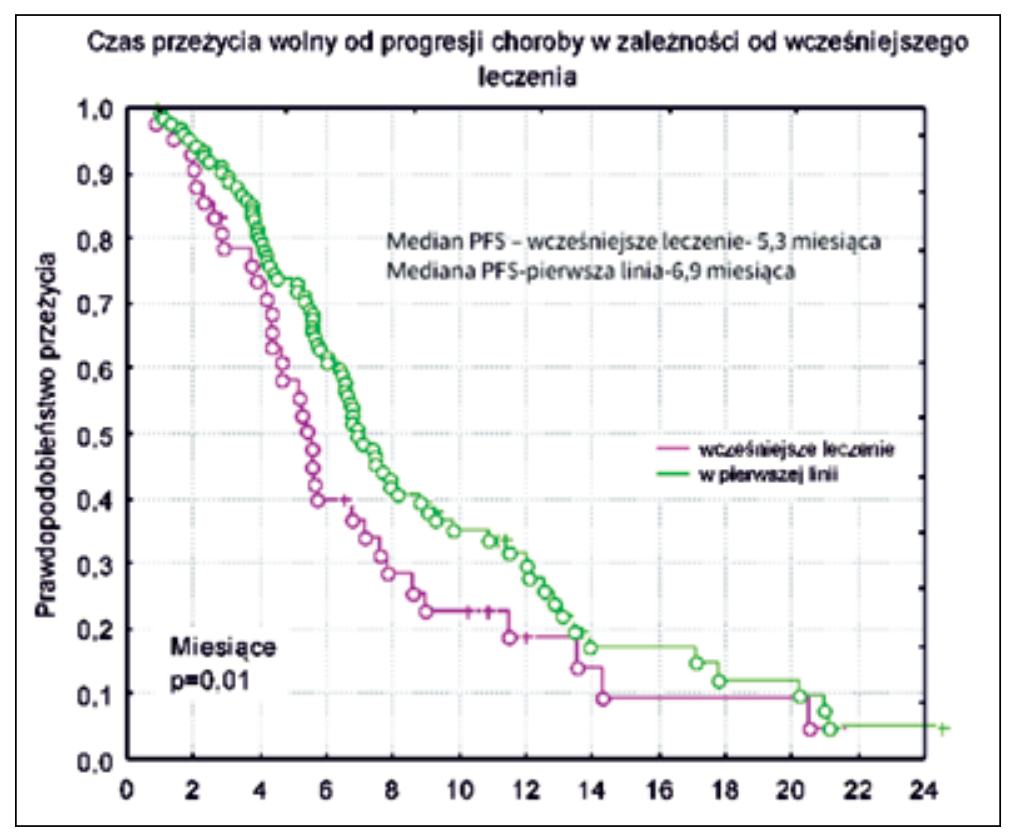

Rycina 3. Przeżycia wolne od progresji choroby w zależności od wcześniejszego leczenia systemowego

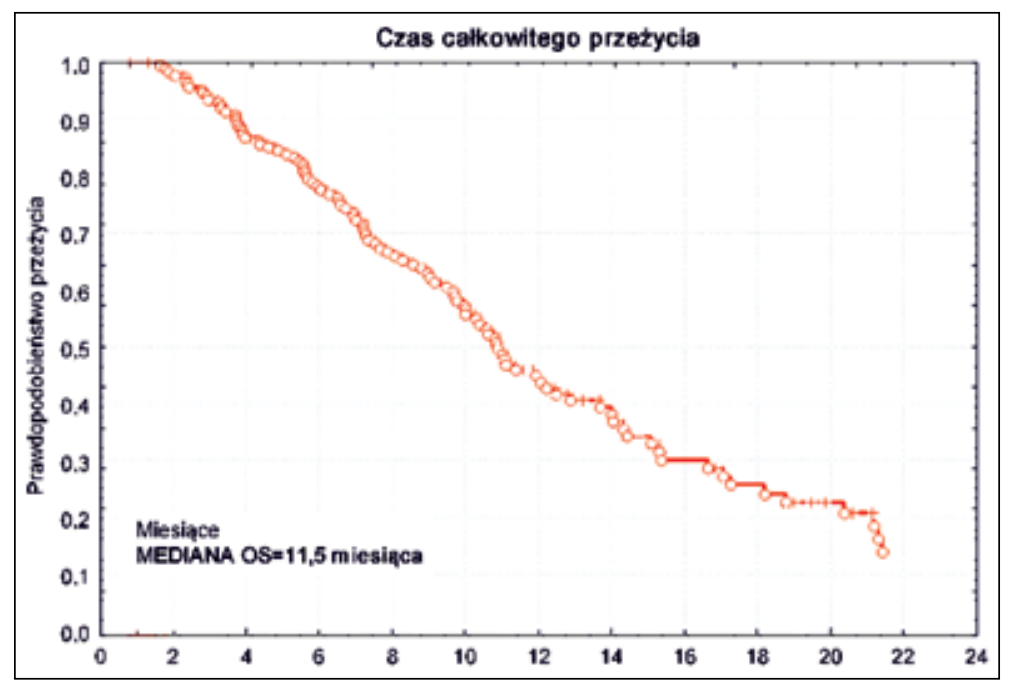

Rycina 4. Krzywa Kaplana-Meiera przedstawiająca przeżycia całkowite chorych leczonych wemurafenibem

Tabela II. Mediany przeżyć (w miesiącach) w zależności od wybranych czynników rokowniczych

\begin{tabular}{lcc}
\hline & $\begin{array}{c}\text { PFS } \\
\text { (wartość } p \text { ) }\end{array}$ & $\begin{array}{c}\text { OS } \\
\text { (wartość } p \text { ) }\end{array}$ \\
\hline ECOG 0 vs 1 & 8 vs 5,5 & 12,5 vs 9,7 \\
& $(p=0,001)$ & $(p=0,02)$ \\
LDH norma vs podwyższone & 7,8 vs 5,2 & 12,8 vs 9,6 \\
& $(p=0,001)$ & $(p=0,04)$ \\
Przerzuty OUN (brak vs obecne) & 7,1 vs 5,6 & 12,2 vs 9,8 \\
& $(p=0,002)$ & $(p=0,4)$ \\
\hline
\end{tabular}

skojarzone charakteryzuje się dłuższymi przeżyciami wolnymi od progresji choroby i przeżyciami całkowitymi [12]. Dwa inne badania III fazy badające wpływ kombinacji inhibitorów BRAF i inhibitorów MEK (dabrafenibu z trametynibem) wykazały wydłużenie median przeżyć całkowitych do około 25 miesięcy oraz wyższy odsetek odpowiedzi na leczenie (64\%-69\%), bez istotnego wpływu na toksyczność leczenia $[13,14]$. Wyniki te doprowadziły do zmiany rekomendacji; obecnie leczenie chorych na zaawansowanego czerniaka 


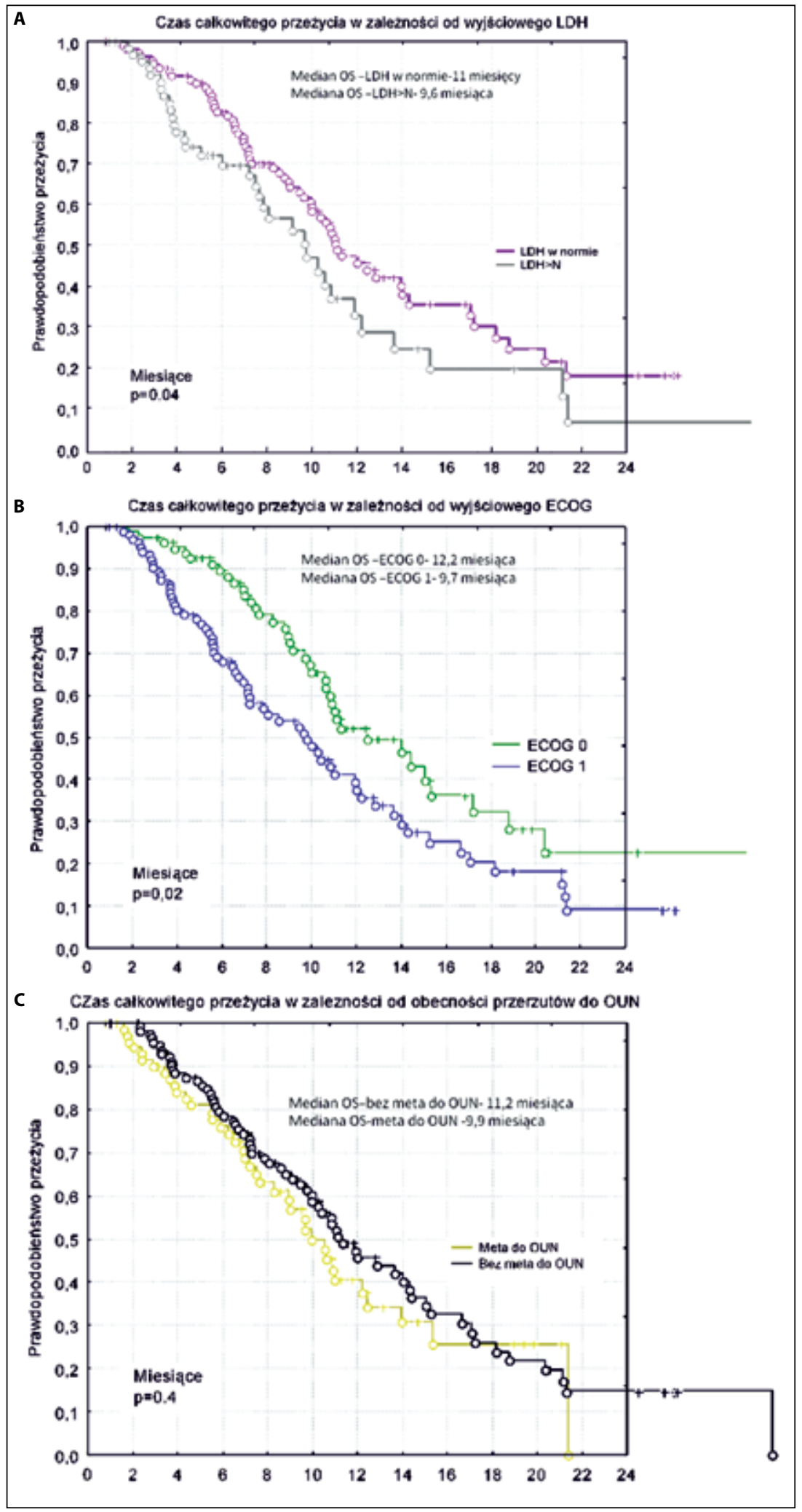

Rycina 5A, B, C. Przeżycia całkowite w zależności od wyjściowej aktywności dehydrogenazy mleczanowej (LDH) - A, stanu sprawności według skali ECOG (Eastern Cooperative Oncology Group) - B oraz obecności zmian przerzutowych w obrębie ośrodkowego układu nerwowego - C 


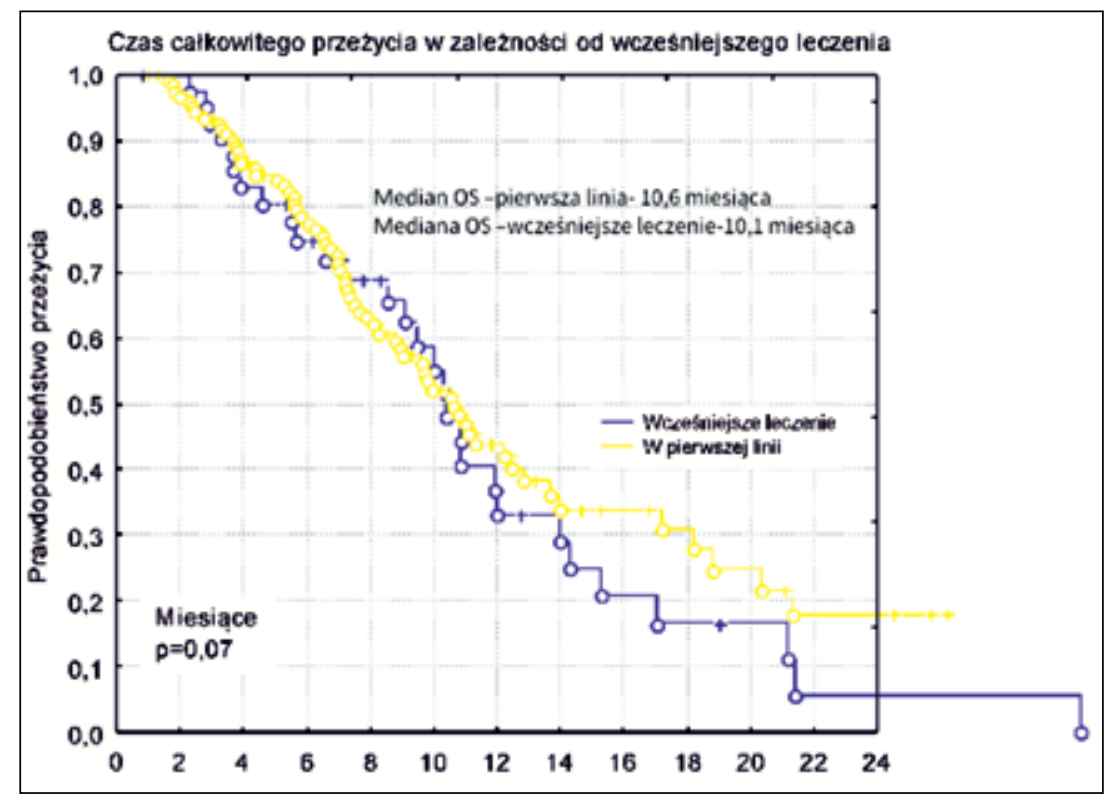

Rycina 6. Przeżycia wolne od progresji choroby w zależności od wcześniejszego leczenia systemowego

z obecnością mutacji BRAF lekami ukierunkowanymi molekularnie powinno być prowadzone za pomocą skojarzenia inhibitorów BRAF i MEK [15].

\section{Wnioski}

Przedstawione wyniki analizy wieloośrodkowej potwierdzają skuteczność i bezpieczeństwo leczenia wemurafenibem w ramach rutynowej praktyki klinicznej w heterogennej grupie zaawansowanych czerniaków z obecnością mutacji BRAF. Dane dotyczące przeżyć całkowitych są zachęcające, zważywszy że jedna czwarta chorych otrzymywała wcześniej leczenie pierwszej linii z powodu rozsiewu choroby. Aktualnie, po zmianie w programie lekowym, która miała miejsce w marcu 2015 r., wemurafenib dostępny jest w Polsce tylko w leczeniu I linii. Uzyskane wyniki analiz wskazują, że obecny kształt programu lekowego ograniczającego stosowanie wemurafenibu (i dabrafenibu) jedynie do pierwszej linii terapii jest niewłaściwy i nieuzasadniony merytorycznie. Ponadto badanie potwierdziło wagę znanych czynników rokowniczych, takich jak aktywność LDH i lokalizacja przerzutów odległych, dla wyników leczenia w monoterapii inhibitorami BRAF.

Leczenie wemurafenibem jest bezpieczne, toksyczność związana z lekiem zazwyczaj ustępuje po czasowym przerwaniu terapii lub modyfikacji dawkowania. Obecne przeżycia chorych w grupie przerzutowych czerniaków z mutacją BRAF są dłuższe niż obserwowane w próbach historycznych, ale intensywne badania nad leczeniem skojarzonym za pomocą inhibitorów szlaku MAPK już teraz stanowią nadzieję na dalszą poprawę przeżyć w tej grupie chorych.

\section{Podziękowania}

Dziękujemy wszystkim chorym biorącym udział w badaniu oraz ich rodzinom. Dziękujemy pracownikom służby zdrowia zaangażowanym w leczenie chorych na czerniaki.

\section{Konflikt interesów}

Piotr Rutkowski otrzymywał honoraria za wykłady od firm Roche, Novartis, GSK, MSD, BMS i Amgen, uczestniczył w posiedzeniach Advisory Board dla powyższych firm. Joanna Stępniak i Hanna Koseła-Paterczyk oraz Małgorzata Mroczek nie zgłaszają konfliktów interesów.

Tomasz Świtaj otrzymał honoraria za wykłady i uczestnictwo w Advisory Board od firm Roche, Novartis, MSD i BMS.

Ewa Kalinka-Warzocha otrzymywała honoraria za wykłady od firm Roche, Novartis, MSD, BMS i Amgen, uczestniczyła w posiedzeniach Advisory Board dla powyższych firm.

\section{Lek. Joanna Stępniak}

Klinika Nowotworów Tkanek Miękkich, Kości i Czerniaków Centrum Onkologii —Instytut im. Marii Skłodowskiej-Curie w Warszawie ul. Roentgena 5, 02-781 Warszawa e-mail:jostepniak@gmail.com

Otrzymano: 5 stycznia 2016 r.

Przyjęto do druku: 3 lutego 2016 r.

\section{Lista stosowanych skrótów}

OS - przeżycia całkowite

PFS - przeżycie wolne od progresji choroby

OUN — ośrodkowy układ nerwowy

LDH - dehydrogenaza mleczanowa 


\section{Piśmiennictwo}

1. Davies $\mathrm{H}$, Bignell GR, Cox C i wsp. Mutations of the BRAF gene in human cancer. Nature 2002; 417: 949-954.

2. Hocker TL, Singh MK, Tsao H. Melanoma genetics and therapeutic approaches in the 21st century: moving from the benchside to the bedside. J Invest Dermatol 2008; 128: 2575-2595.

3. Davies H, Bignell GR, Cox C i wsp. Mutations of the BRAF gene in human cancer. Nature 2002; 417: 949-954.

4. Curtin JA, Busam K, Pinkel D i wsp. Somatic activation of KIT in distinct subtypes of melanoma. J Clin Oncol 2006; 24: 4340-4346.

5. Curtin JA, Fridlyand J, Kageshita T i wsp. Distinct sets of genetic alterations in melanoma. N Engl J Med 2005; 353: 2135-2147.

6. Garrido MC, Bastian BC. KIT as a therapeutic target in melanoma. J/nvest Dermatol 2010; 130, 20-27.

7. Chapman PB, Hauschild A, Robert $C$ i wsp. Improved survival with vemurafenib in melanoma with BRAF V600E mutation. $N$ Engl $J$ Med 2011; 364: 2507-2516.

8. McArthur GA, Chapman PB, Robert C i wsp. Safety and efficacy of vemurafenib in $\mathrm{BRAF}(\mathrm{V} 600 \mathrm{E})$ and $\mathrm{BRAF}(\mathrm{V} 600 \mathrm{~K})$ mutation-positive melanoma (BRIM-3): extended follow-up of a phase 3, randomised, open-label study. Lancet Oncol 2014; 15: 323-332.
9. Larkin J, Del Vecchio M, Ascierto PA i wsp. Vemurafenib in patients with BRAF(V600) mutated metastatic melanoma: an open-label, multicentre, safety study. Lancet Oncol 2014; 15: 436-444.

10. Rutkowski P, Kozak K, Mackiewicz J i wsp. The outcomes of Polish patients with advanced BRAF-positive melanoma treated with vemurafenib in a safety clinical trial. Contemp Oncol 2015; 19: 280-283.

11. Rutkowski P (red). Nowotwory złośliwe skóry. Gdańsk:Via Medica, 2014.

12. Ribas A, Gonzalez R, Pavlick A i wsp. Combination of vemurafenib and cobimetinib in patients with advanced BRAF(V600)-mutated melanoma: a phase 1b study. Lancet Oncol 2014; 15: 954-965.

13. Long GV, Stroyakovskiy D, Gogas $\mathrm{H}$ i wsp. Combined BRAF and MEK inhibition versus BRAF inhibition alone in melanoma. $N$ Engl J Med 2014; 371: 1877-1888.

14. Robert C, Karaszewska B, Schachter J i wsp. Improved overall survival in melanoma with combined dabrafenib and trametinib. N Engl J Med 2015; 372: 30-39.

15. Rutkowski P, Wysocki PJ, Nasierowska-Guttmejer A i wsp. Czerniaki skóry - zalecenia postępowania diagnostyczno-terapeutycznego w 2016 roku. Onkologia w Praktyce Klinicznej 2015; 11: 155-172. 